\title{
Współczesne relacje ekonomiczne pomiędzy Unią Europejską a Chinami
}

\begin{abstract}
Ewa Kędzierska*
Celem niniejszego artykułu jest przedstawienie kierunków rozwoju wspótpracy gospodarczej pomiędzy państwami cztonkowskimi Unii Europejskiej a Chinami. Z przeprowadzonych badañ i analiz wynika, że relacje ekonomiczne Unii Europejskiej $i$ Chin ulegna wzmocnieniu. Gtównym bodźcem intensyfikacji wspótpracy pomiędzy stronami byt globalny kryzys ekonomiczno-finansowy, który doprowadzit do zachwiania równowagi gospodarczej na świecie. Na skutek minionego zatamania gospodarczego powstaty plany intensyfikowania wieloptaszczyznowej wspótpracy, w szczególności poprzez pobudzanie wymiany handlowej i przeptywu inwestycji zagranicznych. Wspótcześnie, największymi europejskimi partnerami handlowymi Chin sa Niemcy, Wielka Brytania, Francja, Wtochy i Holandia. Najbardziej perspektywiczne sektory wspótpracy pomiędzy partnerami to: infrastruktura i transport, rozwiazania umożliwiajace wdrażanie technologii pozyskiwania energii z alternatywnych źródet, transfer technologii przyjaznych dla środowiska naturalnego, maszyny i urzadzenia wysokich technologii.
\end{abstract}

Stowa kluczowe: handel zagraniczny, inwestycje, UE, Chiny.

Nadesłany: 15.07.2014 | Zaakceptowany do druku: 2.09.2014

\section{Contemporary economic relations between European Union and China}

The purpose of this article is to present the directions of development of economic cooperation between the EU-Member States and China. Various research and analyses show that the economic relations between the European Union and China will be strengthened. The main stimulus to intensify cooperation between the parties was the global economic and financial crisis, which led to economic imbalances in the world. As a result of the economic downturn of the past, plans to intensify cooperation on various levels arose, in particular by stimulating trade and flow of foreign investment. Today, the largest European trading partners for China are Germany, Great Britain, France, Italy and the Netherlands. The most promising sectors of cooperation between the partners are: infrastructure and transport, solutions for deploying technologies for alternative energy sources, transfer of green technologies, machinery and high technology equipment.

Keywords: international trade, investments, EU, China.

Submitted: 15.07.2014 | Accepted: 2.09.2014

JEL: F00

\footnotetext{
* Mgr Ewa Kędzierska - Wydział Zarządzania Uniwersytetu Warszawskiego.

Adres do korespondencji: Wydział Zarządzania Uniwersytetu Warszawskiego, ul. Szturmowa 1/3, 02-678

Warszawa; e-mail: ewa.kedzierska@outlook.com.
} 


\section{Wprowadzenie}

Na skutek efektów globalnego kryzysu finansowego tempo rozwojowe czołowych gospodarek światowych uległo znacznemu spowolnieniu. Dotychczasowe dominujące koncepcje ekonomiczne oraz systemy finansowe wielu państw podlegają szeregowi dostosowań. Ponownej analizie i dyskusji poddawane są problemy regulacji rynku, zakresu interwencjonizmu państwowego, liberalizacji i integracji rynków. Wspó1cześnie wiele gospodarek wschodzących (ang. emerging markets) staje przed szansa wzmocnienia i zaakcentowania swojej pozycji na arenie międzynarodowej. Jednym z największych wschodzących ekonomicznych gigantów są Chiny, które na polityczno-gospodarczej mapie świata zaczęły ogrywać szczególną rolę, w szczególności jako patron liberalizacji międzynarodowej wymiany handlowej oraz intensyfikacji współpracy inwestycyjnej. Wskutek ponad trzydziestoletniego dynamicznego rozwoju gospodarki Chiny mają szansę wejść do grona graczy kreujących globalne rozwiązania. Dzięki intensyfikacji programów badawczo-rozwojowych nad nowymi technologiami oraz wspieraniu innowacyjności w kraju, a także wysokiemu udziałowi inwestycji zagranicznych Chiny zaczęły spełniać czołową funkcję w światowym układzie gospodarczym (Pieczonka, 2012).

Współczesne założenia chińskiego modelu gospodarczo-politycznego opieraja się na następujących założeniach:

- pragmatyczne, pozbawione ideologii podejście rządu chińskiego do reform i koniecznych zmian, zwłaszcza w kwestii naukowego rozwoju państwa,

- stopniowe, ostrożne dawkowanie zmian i reform, z możliwościa wycofania sie $\mathrm{z}$ nich $\mathrm{w}$ przypadku błędu lub niepowodzenia,

- trzeźwa ocena własnych możliwości i szans połączona z chłodną kalkulacją nowych opcji wyłaniających się ze stale zmieniającego się otoczenia globalnego,

- aktywny udział aparatu państwowego w procesach rozwojowych i gospodarczych, w przeciwieństwie do neoliberalnych założeń słabego państwa,

- interwencjonizm państwowy nakazujący utrzymanie kontroli nad dużymi zakładami przemysłowymi w strategicznych sektorach gospodarki, takich jak: przemysł zbrojeniowy, bankowość, produk- cja energii elektrycznej, przemysł petrochemiczny, telekomunikacja, lotnictwo cywilne oraz przemysł stoczniowy,

- zaangażowanie państwa w proces rozwoju kraju, na bazie chińskich tradycji, z pomocą świadomych, dobrze wykształconych i dobranych elit rządzących,

- powrót do merytokracji, systemu rotacji kadr oraz zastępowania jednej generacji przywódców inną, lepiej wykształconą, wypracowanych przez Denga Xiaopinga,

- stosowanie się do zasady „rynek przed demokracją", zgodnie z którą reformy rynkowe poprzedzają działania o charakterze demokratycznym,

- postepowanie we wszystkich dziedzinach życia gospodarczego i społecznego zgodnie z zasadami zrównoważonego rozwoju (ang. sustainable development), budowa harmonijnego społeczeństwa (chiń. hexie shehui) w myśl konfucjanizmu,

- transformacja gospodarki oparta na internacjonalizacji i globalizacji procesów, intensyfikacja rozwoju gospodarczego i technologicznego, tzn. dynamiczny rozwój chińskiego programu kosmicznego, ekspansja na rynki światowe chińskich marek sektora technologii informatycznych, takich jak: Lenovo, Huawei, ZTE (Góralczyk, 2013).

W okresie wyprowadzania gospodarek zachodnich $\mathrm{z}$ pokryzysowej recesji przyciągnięcie chińskiego kapitału stanowi jeden z najważniejszych celów budowanej polityki zagranicznej. Współczesna ekonomiczna sytuacja miedzynarodowa sprzyja powstaniu korzystnych warunków realizacji chińskiej polityki, np. w zakresie pozyskiwania nowoczesnych technologii poprzez transakcje fuzji i przejęć czy wchodzenie na nowe rynki zbytu. Szczególną rolę w chińskiej strategii odgrywają relacje handlowe oraz inicjatywy inwestycyjne podejmowane z państwami Unii Europejskiej. Głównym bodźcem wzmocnienia wspólpracy pomiędzy stronami był globalny kryzys ekonomiczno-finansowy, który doprowadził do zachwiania równowagi gospodarczej na świecie. Zintensyfikowanie i pogłębienie relacji gospodarczych pomiędzy państwami Unii Europejskiej a Chinami leży w interesie obydwu stron. Zasoby kapitałowe partnera azjatyckiego są szansą na pobudzenie gospodarek w Europie poprzez inwestycje oraz dodatkowy zastrzyk pieniadza. Ponadto wzrastająca zamożność społe- 
czeństwa chińskiego oraz zapotrzebowanie rynku na luksusowe i prestiżowe produkty wysokiej jakości stanowią istotną szansę na wzrost eksportu do Azji. Również europejskie know-how w zakresie przemysłu wysokiej techniki oraz nowoczesne modele zarządzania są cennymi źródłami rozwiązań dla ukierunkowanej na innowacyjne rozwiązania i globalna ekspansję gospodarki chińskiej (Pieczonka, 2012).

\section{Polityka współpracy gospodarczej pomiędzy Unią Europejską a Chińską Republiką Ludową}

Relacje ekonomiczne Unii Europejskiej i Chińskiej Republiki Ludowej w pierwszej dekadzie XXI wieku uległy znacznemu rozwojowi. Głównym bodźcem wzmocnienia współpracy pomiędzy stronami by globalny kryzys ekonomiczno-finansowy, który doprowadził do zachwiania równowagi gospodarczej na świecie. Rynek Unii Europejskiej jest największym odbiorcą chińskiego eksportu. Bezpośrednio po Japonii stanowi największe źródło pochodzenia towarów zagranicznych. Największymi europejskimi partnerami handlowymi Chin są: Niemcy, Wielka Brytania, Francja, Włochy i Holandia (Puślecki, 2012).

Chiny oraz państwa członkowskie Unii Europejskiej zmagają się z licznymi perturbacjami gospodarczymi. Problemy i niedogodności partnera azjatyckiego związane są $\mathrm{z}$ zanieczyszczeniem środowiska $\mathrm{i}$ jego postępującą degradacją oraz wyczerpujacymi się konwencjonalnymi źródłami energii, które w kontekście szybkiego wzrostu gospodarczego stanowią istotną barierę rozwojowa. W ramach trwającego procesu transformacji gospodarki kontynuowane sa inicjatywy związane $\mathrm{z}$ pobudzaniem konsumpcji na rynku wewnętrznym, modernizacją produkcji przemysłowej Chin, intensyfikacją industrializacji i urbanizacji kraju. Głównym celem Chin jest przeniesienie nacisku z produkcji eksportowej na pobudzanie popytu wewnętrznego. Państwa europejskie zmagają się z koniecznościa zwiększania nakładów na działalność badawczo-rozwojową oraz poszukiwania własnych, nowych rozwiązań technologicznych. Ponadto państwa Unii Europejskiej borykają się z problemami nieelastycznych systemów zatrudnienia, trudnością w przekwalifikowaniu kadry pracowniczej, deficytem budżetowym, wysokimi stopami bezrobocia oraz nadmiernymi obciążeniami budżetów wydatkami socjalnymi (Puślecki, 2012).

Na skutek minionego kryzysu powstały plany pobudzania gospodarek Państwa Srodka i Unii Europejskiej dzięki umacnianiu wielopłaszczyznowej współpracy, w szczególności poprzez pobudzanie wymiany handlowej i przepływu inwestycji zagranicznych. Najbardziej perspektywiczne sektory wymiany towarów i usług pomiędzy partnerami to:

- infrastruktura i transport,

- rozwiązania umożliwiające wdrażanie technologii pozyskiwania energii z alternatywnych źródeł,

- transfer technologii przyjaznych dla środowiska naturalnego,

- maszyny i urządzenia wysokich technologii (high-tech) (Puślecki, 2012).

Oficjalna współpraca gospodarcza pomiędzy Wspólnotami Europejskimi i Chińską Republiką Ludową rozpoczęła sie w drugiej połowie lat 70 . XX wieku, kiedy podpisano pierwszą umowę handlową oraz rozpoczęto kooperację naukowo-techniczną. W 1985 roku podpisano Porozumienie o Współpracy Handlowej i Ekonomicznej zakładające:

- zastosowanie klauzuli najwyższego uprzywilejowania dotyczacej ceł i opłat handlowych pomiędzy Chinami i państwami Unii Europejskiej,

- intensyfikację importu z krajów Wspólnoty Europejskiej poprzez stworzenie przez stronę chińską korzystnych warunków ułatwiających wymianę handlową,

- wprowadzenie mechanizmów wolnorynkowych odnośnie do ustalania poziomu cen towarów i usług,

- ułatwienie przepływu osób prowadzących działalność handlowa.

Ponadto porozumienie zawierało zapisy dotyczące zacieśnienia współpracy w rolnictwie, sektorach przemysłowych, energetyce, transporcie oraz wspólnych pracach badawczo-rozwojowych i ochronie środowiska naturalnego (Gradzka i Kania, 2010).

Odzwierciedleniem postępującego rozwoju stosunków gospodarczych pomiędzy partnerami było podpisanie w 1995 roku „Długookresowej polityki stosunków między Europą a Chinami”, a następnie zawiazanie w 2000 roku „Porozumienia dwustronnego UE-Chiny w sprawie akcesji 
Chin do WTO”. Unia Europejska podjęła wówczas działania w kwestii przekształcenia przepisów antydumpingowych w celu zniesienia ograniczeń ilościowych dla eksportu towarów z Chin. Szereg zmian dokonywanych po stronie partnera zarówno chińskiego, jak i europejskiego doprowadził do wzmocnienia stosunków gospodarczych oraz chęci poszerzania współpracy w nowych obszarach (Gradzka i Kania, 2010).

Intensyfikacja współpracy pomiędzy partnerami nastapiła w 2006 r. podczas dziewiątego szczytu UE-Chiny, kiedy rozpoczęto rozmowy na temat podpisania nowego „Porozumienia o partnerstwie i współpracy pomiędzy Chinami a Unią Europejską" (ang. China-EU Partnership and Cooperation Agreement, PCA). Chińska Republika Ludowa i Wspólnota Europejska stały się wówczas największymi partnerami handlowymi. W porozumieniu podkreślono strategiczne partnerstwo pomiędzy stronami w zakresie ponad 20 obszarów współpracy. Dokument ma zastapić podpisane w 1985 roku „Porozumienie o współpracy handlowej i ekonomicznej" (Puślecki, 2012). Celem podpisania nowego porozumienia jest pogłębienie relacji ekonomicznych oraz kooperacja w nowych dziedzinach: badań naukowych, wymiany kulturalnej, ochrony środowiska, pozyskiwania energii z alternatywnych źródeł. Głównym czynnikiem wpływającym na wydłużony czas i dwutorowość negocjacji PCA są odmienne oczekiwania Chin i Unil Europejskiej względem siebie. Państwa Wspólnoty oczekują od Chin większego zaangażowania na arenie miedzynarodowej oraz implementacji europejskich standardów i rozwiązań do swojego systemu gospodarczo-politycznego. Co więcej: państwa UE postrzegają PCA jako pojedyncze kompleksowe porozumienie, które umożliwi Chinom szybszy rozwój w myśl założeń otwartego społeczeństwa, zrównoważonego rozwoju oraz dbałości o relacje ekonomiczne i handlowe z Unią. Dla Chin podpisywanie tego typu porozumienia nie jest typową praktyką z zakresu polityki zagranicznej. Ponadto Chiny negatywnie odnosza się do działań UE w krajach rozwijających się i domagają się akceptacji chińskiego modelu rozwoju gospodarczego (Zhang, 2011). Kwestiami spornymi, wydłużającymi negocjacje układu, są m.in. demokratyzacja Chin, problematyka ochrony praw czło- wieka i poszanowania dla praw autorskich, a także stopniowe znoszenie embarga na handel bronia (Gradzka i Kania, 2010).

$\mathrm{W}$ analizowanym okresie wydano także materiał podkreślający bliskie relacje pomiędzy partnerami: dokument „UEChiny: Bliżsi partnerzy, rosnaca odpowiedzialność" (ang. EU-China: Closer Partners, Growing Responsibilities) oraz dołaczone stanowisko Unii Europejskiej: „Konkurencja i partnerstwo" (ang. Competition and Partnership), w którym zawarto priorytety unijnej polityki w zakresie handlu i inwestycji w stosunku do partnera chińskiego, ściśle związane $\mathrm{z}$ zobowiązaniami Chin wynikającymi z przystapienia do Światowej Organizacji Handlu. W swoim stanowisku państwa europejskie podkreśliły konieczność liberalizacji rynku chińskiego oraz podjęcia działań na rzecz ochrony praw własności intelektualnej (Puślecki, 2012).

Współcześnie partnerzy opierają swoje relacje gospodarcze na „Strategicznym Programie Współpracy Chin i Unii Europejskiej do roku 2020" (ang. EU-China 2020 Strategic Agenda for Cooperation), który stanowi kompilację założeń chińskiego 12. Planu Pięcioletniego oraz unijnej „Strategii Europa 2020". Porozumienie opiera się na czterech głównych filarach współpracy oraz licznych dialogach sektorowych, m.in. w dziedzinie utrzymywania pokoju i bezpieczeństwa, wymiany handlowej i inwestycji zagranicznych, rozwoju przemysłu, nauki, transferu technologii oraz wspierania innowacyjności, badań nad przestrzenią kosmiczną, sektorem energetycznym, zmianami klimatycznymi i ochrona środowiska, rozwojem społecznym, kulturą i edukacją młodzieży (EU-China 2020 Strategic Agenda for Cooperation).

Najbardziej rozbudowanym filarem „Strategicznego programu współpracy Chin i Unii Europejskiej do roku 2020" jest problematyka budowania dobrobytu (ang. prosperity) w myśl założeń strategii „wygrany-wygrany” (ang. win-win strategy). Jedną z kluczowych inicjatyw programu jest umocnienie relacji gospodarczych w zakresie wymiany handlowej i inwestycji zagranicznych w duchu wzajemnych korzyści, poprzez propagowanie otwartego, przejrzystego rynku i równych szans zarówno dla inwestorów chińskich w Unii Europejskiej oraz przedsiębiorców europejskich w Chinach. Szczególne znaczenie ma wzmoc- 
nienie perspektyw poprawy warunków dla rozwoju firm z sektora małych i średnich przedsiębiorstw. W ramach „Strategicznego programu współpracy Chin i Unii Europejskiej do roku 2020" przewidziano negocjacje zapisów i podpisanie „Porozumienia inwestycyjnego pomiędzy Unią Europejską a Chinami" (ang. EU-China Investment Agreement) oraz „Strategicznych ram współpracy celnej w latach 2014-2017" (ang. Strategic Framework for EU-China Customs Cooperation for 2014-2017). Porozumienie inwestycyjne obejmuje zagadnienia dotyczące ułatwienia dostępu do rynków w zakresie przepływu towarów, usług i kapitału poprzez postępującą liberalizację prawa handlowego i eliminację restrykcyjnych zapisów dotyczących inwestycji zagranicznych. Ponadto porozumienie ma zastapić indywidualne umowy bilateralne państw członkowskich UE podpisywane z partnerem chińskim na rzecz jednego, wszechstronnego porozumienia obejmującego cała Wspólnote Europejska (EU-China 2020 Strategic Agenda for Cooperation).

Kolejnym istotnym założeniem programu współpracy jest zwiększenie wymiany poglądów na temat polityki w zakresie zamówień publicznych w ramach „Porozumienia w sprawie zamówień rzadowych" (ang. Agreement on Government Procurement) w celu przyspieszenia ukończenia procesu akcesji Chin do Światowej Organizacji Handlu. Ponadto, w ramach programu promowane jest wzmocnienie kooperacji pomiędzy kluczowymi instytucjami finansowymi: Chińskim i Europejskim Bankiem Inwestycyjnym, Europejskim Bankiem Odbudowy i Rozwoju, a także pomiędzy Ludowym Bankiem Chin i Europejskim Bankiem Centralnym w ramach „Dwustronnej Umowy Wymiany Waluty" (ang. Chinese Yuan/Euro Bilateral Currency Swap Agreement). Innymi istotnymi kwestiami zawartymi w programie sa m.in.: ścisła współpraca w zakresie prawa ochrony własności intelektualnej, ujednolicenie systemów przepływu informacji (ang. Europe-China Standardisation Information Platform), ochrona wyrobów regionalnych, zwiększenie dostępu do instrumentów finansowych dla małych i średnich przedsiębiorstw (EU-China 2020 Strategic Agenda for Cooperation).

\section{Charakterystyka wymiany handlowej Unii Europejskiej i Chin}

Chińska Republika Ludowa jest drugą największą gospodarką świata oraz największym graczem w zakresie obrotów handlu zagranicznego. Wzrost gospodarczy Chin osiagnał w 2013 roku 7,7\%. Szacuje się, że w ciągu najbliższych kilku lat ponad $90 \%$ światowego wzrostu ekonomicznego będzie generowane poza Europa, z czego jedna trzecia w Chinach. Środowisko międzynarodowe przewiduje, że w przeciągu 10 lat Chiny staną się największą gospodarką świata o ogromnym potencjale, posiadającą w 2015 roku ponad 1,39 miliarda konsumentów. Każdego roku 20 milionów chińskich gospodarstw domowych przekracza próg dochodu 13500 dolarów, co umożliwia awans do średniej klasy społecznej pod wzgledem ekonomicznym (ang. middle class families). Pomimo zwalniającego poziomu wzrostu konsumpcji na rzecz intensyfikacji inwestycji, dzięki zwiększonym możliwościom nabywczym chińskie gospodarstwa domowe stanowią atrakcyjny segment odbiorców dla importowanych, europejskich dóbr konsumpcyjnych w szczególności z rynku luksusowych samochodów osobowych (European Commision, 2014).

Współcześnie wymiana handlowa pomiędzy Unią Europejską a Chińską Republiką Ludowa osiaga codziennie wartość ponad miliarda euro. Dwadzieścia lat temu relacje handlowe pomiędzy UE a Chinami nie istniały. Aktualnie współpraca pomiędzy Chinami i UE stanowi druga największa platformę kooperacji gospodarczej na świecie. W ciagu dwudziestu lat gospodarki Chin i UE zintensyfikowały procesy integracyjne, osiagajac w 2013 roku poziom wymiany handlowej wynoszący ponad 428 miliardów euro. Według danych Komisji Europejskiej największym potencjałem rozwoju charakteryzuje się sfera wymiany usług, która w 2012 roku osiąnęła wartość zaledwie 49,9 miliarda euro (European Commision, 2014). Zestawienie wielkości obrotów handlowych pomiędzy Unią Europejską a Chińską Republiką Ludową w latach 2004-2013 przedstawia rysunek 1. 
Rysunek 1. Poziom wymiany handlowej Unii Europejskiej z Chińską Republiką Ludową w latach 2004-2013 [w mld EUR]

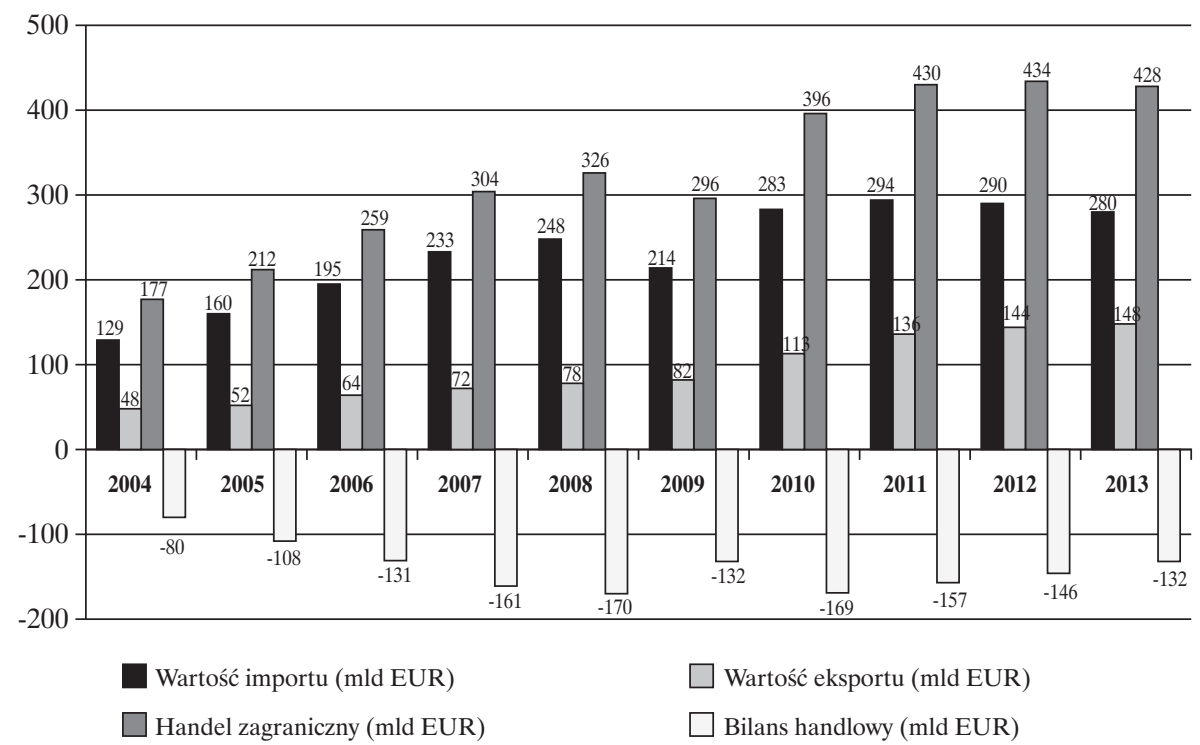

Źródło: opracowanie własne na podstawie: European Commision Directorate General for Trade, China - Trade Statistics, 2013, http://trade.ec.europa.eu/doclib/docs/2006/september/tradoc_113366.pdf (07.04.2014)

Chiny są najszybciej rosnącym rynkiem dla europejskich produktów eksportowych. Pomimo zwalniającego tempa wzrostu chińskiego PKB w perspektywie długookresowej strategiczna pozycja chińskiego rynku dla przedsiębiorców z Unii Europejskie będzie się umacniać. Według wstępnych szacunków Komisji Europejskiej w 2013 r. eksport Unii Europejskiej do Chin wzrósł o 2,9\% (rysunek 2) i osiągnął wartość około 148,1 miliarda euro. W 2009 r. Chiny osiągnęły status największego eksportera na świecie, a w 2013 r. odnotowały najwyższą na świecie wartość obrotu handlu zagranicznego, wynosząca ponad 4 biliony dolarów amerykańskich. W latach 2008-2013 europejski eksport do Chin wzrósł dwukrotnie, przyczyniając się do trendu równoważącego wymianę handlową pomiędzy partnerami. Chiny są największym dostawca towarów w UE o wartości importu równej około 279,9 miliarda euro. Unia Europejska oraz Chiny daża do zrównoważenia bilansu obrotów handlowych. W 2013 r. względem roku 2012 import z Chin spadł o $4 \%$ w ujęciu rocznym, o 11,7 mld euro (rysunek 2). Ujemny bilans handlowy UE wzgledem Chin wygenerowały przepływy dóbr i usług głównie z sektora telekomunikacyjnego, obuwia i tekstyliów oraz przemysłu metalurgicznego (żelaza i stali) (European Commision, 2014).

Wzrost eksportu europejskich towarów do Chin spowodowany był liberalizacją prawa handlowego wskutek przystąpienia Chin w 2001 r. do Swiatowej Organizacji Handlu. Ułatwienie dostępu do rynku, niskie koszty pracy, brak składek emerytalnych i ubezpieczeń społecznych, a także niskie podatki przyczyniły się do ekspansji europejskich korporacji transnarodowych w Państwie Środka. Wzrost importu z Chin wywołany był korzystnym dla chińskich eksporterów kursem walutowym juana w stosunku do euro, a także rozszerzeniem Unii Europejskiej w 2004 i 2007 roku o państwa z regionu Europy Srodkowo-Wschodniej, co doprowadziło do powiększenia rynku 
Rysunek 2. Dynamika wymiany handlowej Unii Europejskiej z Chińską Republiką Ludową w latach 2004-2013 (w \%)

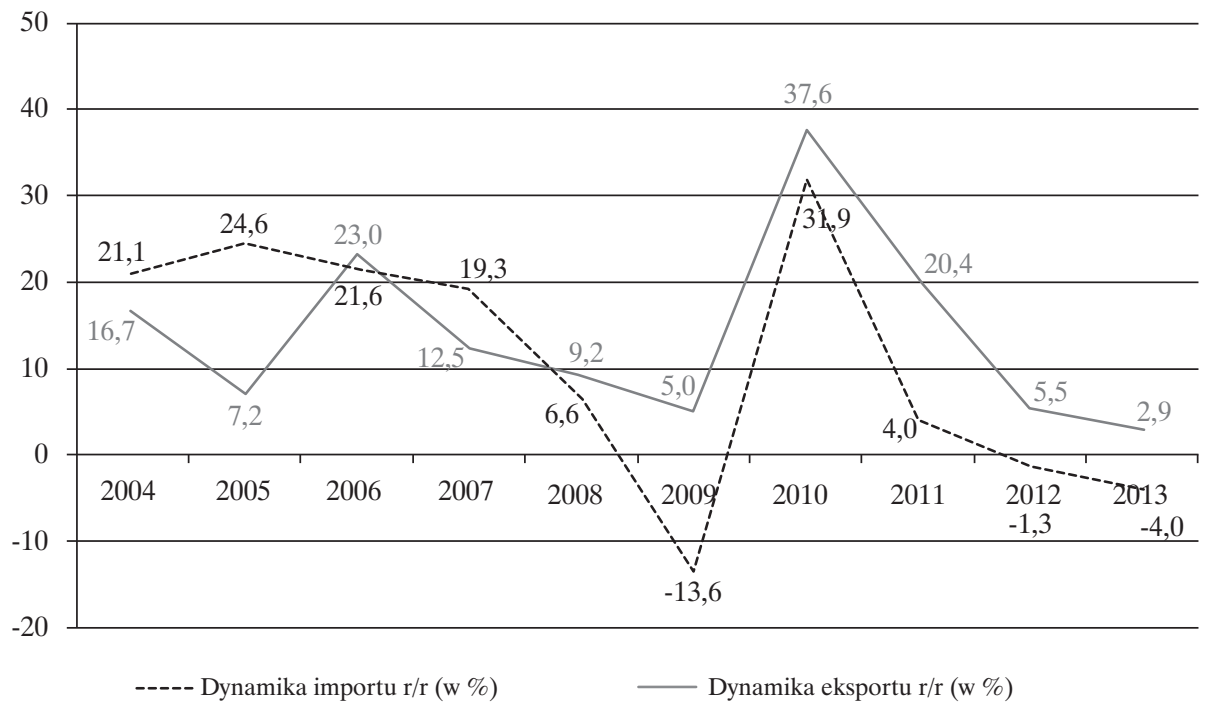

Źródło: opracowanie własne na podstawie: European Commision Directorate General for Trade, China - Trade Statistics 2013, http://trade.ec.europa.eu/doclib/docs/2006/september/tradoc_113366.pdf (07.04.2014).

Rysunek 3. Prognoza wartości bilansu handlowego Unii Europejskiej względem Chin w ujęciu kwartalnym do I połowy 2015 roku (w mld EUR)

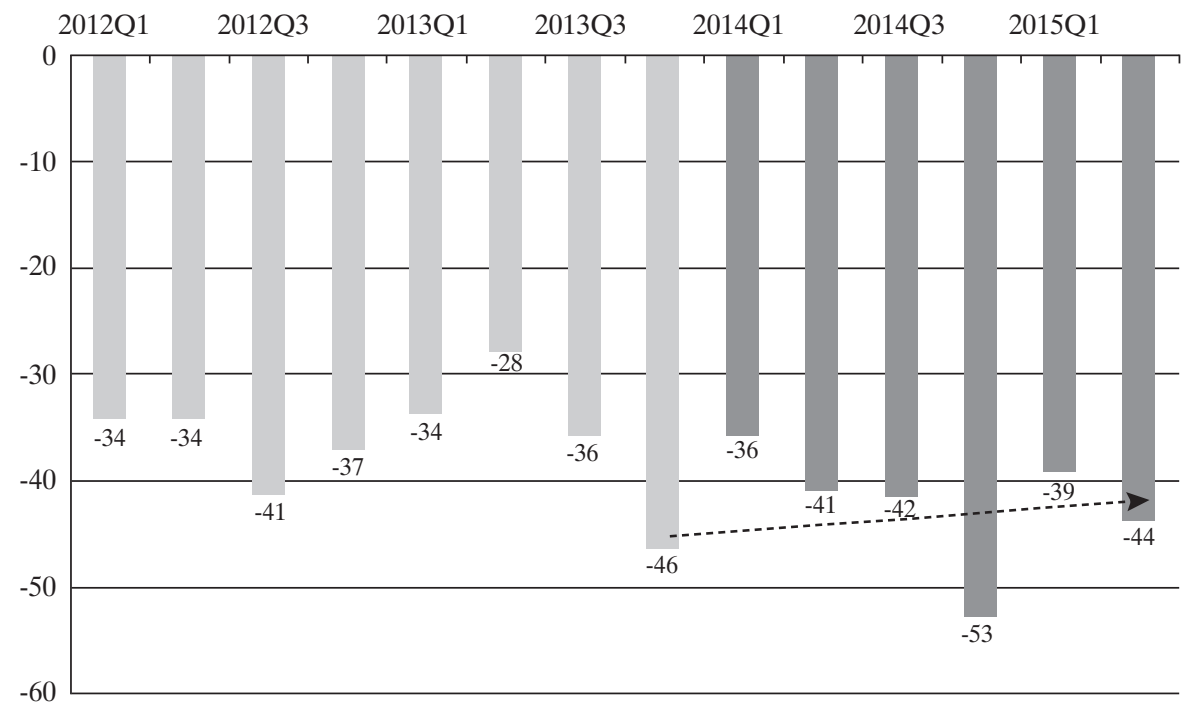

Źródło: opracowanie własne na podstawie: European Union Framework Contract Commission 2011 (2013). EU-China Economic Observatory, s. 31, http://trade.ec.europa.eu/doclib/docs/2014/january/ tradoc_152055.pdf (08.04.2014). 
potencjalnych konsumentów w UE o około 20\%. W 2005 r., wskutek wygaśnięcia „Porozumienia Wielowłóknowego" (ang. Multi Fibre Agreement) z 1974 r. chiński eksport odzieży i tekstyliów uzyskał ułatwiony dostęp do unijnego rynku (Puślecki, 2012).

Redukcja deficytu bilansu handlowego Unii Europejskiej z Chinami jest jednym z głównych założeń współczesnej polityki współpracy gospodarczej zarówno Chin oraz państw członkowskich UE. Niwelowanie ujemnego bilansu handlowego UE ma zostać osiągnięte poprzez utrzymywanie importu na stałym poziomie oraz intensyfikacje eksportu towarów i usług na dynamicznie rozwijający rynek chiński (rysunek 3). Dla porównania, współcześnie państwa Unii Europejskiej wciąż eksportują ponad 2,5 razy więcej usług do Szwajcarii (82,9 mld euro) niż do Chin (29,8 mld euro), a całkowity poziom eksportu towarów i usług do Szwajcarii (216,3 mld euro) jest o 42,6 miliarda euro większy niż poziom eksportu do Chin (173,7 mld euro) (European Commision, 2014).

\section{Przepływ Bezpośrednich Inwestycji Zagranicznych pomiędzy Unią Europejska a Chinami}

Według badań Eurostatu chińskie Bezpośrednie Inwestycje Zagraniczne (BIZ) w Unii Europejskiej stanowiły w 2012 r. zaledwie 2,6\% całkowitego napływu inwestycji do państw członkowskich UE. Chińskie przedsiębiorstwa zainwestowały w UE w 2012 r. 7,6 miliarda euro. Dla porównania, udział całkowitego przepływu BIZ z Unii Europejskiej utrzymuje się na stabilnym poziomie $20 \%$ wartości całkowitego napływu inwestycji do Chin. Unia Europejska znajduje się grupie pięciu największych dostawców BIZ w Chinach obok Tajwanu, Hong Kongu, Stanów Zjednoczonych Ameryki i Japonii. Europejskie przedsiębiorstwa zainwestowały w Chinach w 2012 r. 15,5 miliarda euro. W sektorze finansowym na koniec 2012 r. banki chińskie posiadały udział w rynku wynoszący zaledwie 1,82\%. Europejskie firmy działajace w sektorze usług podkreślają, że wejście na rynek chiński utrudnione jest przez biurokrację oraz długie i skomplikowane procedury. Ponadto, chiński rząd dąży do utrzymania wyłączności dla firm krajowych w sektorze bankowym, w branży budowlanej i telekomunikacji. (European Commision, 2014).

Istotnym problemem uniemożliwiającym poznanie chińskiego rynku jest zakaz zatrudniania chińskich prawników w zagranicznych kancelariach prawnych oraz możliwość uzyskiwania kwalifikacji z zakresu prawa chińskiego przez prawników spoza Chin. Zagraniczne firmy maja ograniczony dostęp do przetargów publicznych ze względu na brak transparentności, niesprawiedliwe rozstrzyganie przetargów oraz niezadowalające procedury odwoławcze. Zagraniczne firmy próbujące wejść na chiński rynek muszą się zmierzyć z szeregiem barier handlowych. Chińskie prawodawstwo oparte jest na specyficznych standardach, które bardzo często są niezrozumiałe dla inwestorów zagranicznych. Inne zagadnienia, które niepokoja miedzynarodowe środowisko biznesowe w Chinach, to brak równych szans dla cudzoziemców, kwestie dotacji i finansowania inwestycji, problematyka transparentności i przewidywalności kierunków działalności rządu chińskiego w kwestii tworzenia przepisów prawa. Według badań Europejskiej Izby Handlowej $45 \%$ europejskich firm prosperujących na rynku chińskim odnotowało utracone możliwości rozwoju działalności oraz zmierzyło się z barierami wejścia na rynek związanymi z krajowymi regulacjami (European Commision, 2014).

Charakter chińskich BIZ na rynku europejskim uwarunkowany jest przede wszystkim chęcią zdobycia dostępu do nowoczesnych technologii poprzez fuzje i przejęcia europejskich przedsiębiorstw (ang. Mergers \& Acquisitions, M\&A). Szczególnie atrakcyjnym sektorem dla inwestorów chińskich jest przemysł wysokiej i średniej techniki, energetyka, transport czy rynek nieruchomości. Z kolei najwięcej chińskich przedsiębiorstw produkcyjnych prosperuje w branży maszyn i urządzeń elektrycznych, elektronice czy branży tekstylnej (rysunek 4). Ponadto chińskie przedsiębiorstwa poprzez transakcje M\&A unikają barier handlowych ograniczających eksport chińskich towarów i usług do Unii Europejskiej. Wskutek kryzysu finansowego, który osłabił kurs euro oraz naraził wiele europejskich firm na problemy finansowe, fuzje i przejecia na rynku europejskim stały się bardzo atrakcyjną formą inwestowania dla chińskich podmiotów. Największe przejęcie przez chiński 
Sinopec firmy Addax Petroleum z siedziba w Szwajcarii było transakcją o wartości 7,2 miliarda dolarów (Gradziuk i Szczudlik-Ta- tar, 2012). Zestawienie najważniejszych kontraktów fuzji i przejęć chińskich przedsiębiorstw w Europie przedstawia tabela 1.

Rysunek 4. Sektory działalności chińskich firm produkcyjnych w 2013 roku w Europie

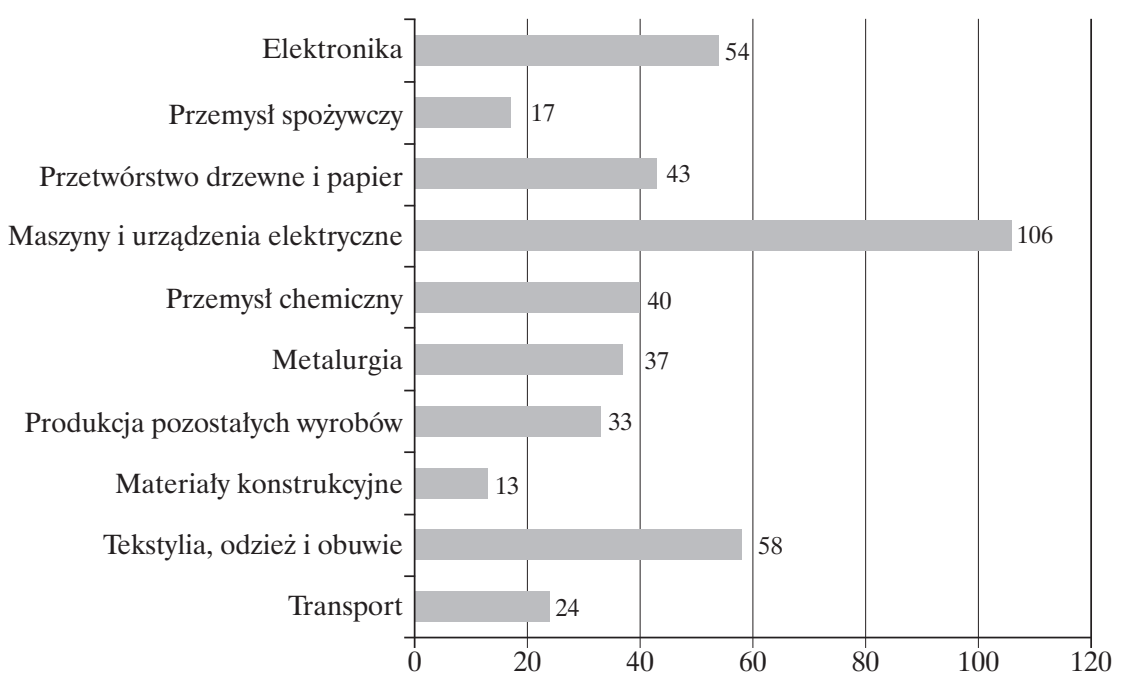

Źródło: opracowanie własne na podstawie: Antwerp Management School (2013).

Ekspansja chińskich przedsiębiorstw na rynek europejski rozpoczeła sie na przełomie XX i XXI wieku, około roku 2000. Średnia wieku chińskich firm w Europie wynosi 8 lat, a zaledwie $1 / 4 \mathrm{Z}$ nich przetrwała na rynku dłużej niż 10 lat. Głównymi motywami skłaniającymi chińskie przedsiębiorstwa prywatne do wejścia na rynek europejski są możliwości przejęć lokalnych firm oraz pozyskanie nowych technologii i know-how w zakresie wytwarzania i sprzedaży towarów. Przedsiębiorstwa państwowe zainteresowane są głównie inwestycjami w branże wrażliwe UE: przemysł stoczniowy, stalowy, górnictwo węgla, przemysł samochodowy, przemysł włókien sztucznych oraz przemysł tekstylny i odzieżowy. Dominującą grupą chińskich podmiotów gospodarczych w Europie sa małe i średnie prywatne firmy oraz rodzinne biznesy lokowane w Europie Srodkowo-Wschodniej. Ze względu na przewagi kosztowe chińscy przedsiębiorcy upatrują szans na międzynarodowa ekspansje rynkowa. Europa postrzegana jest przez nich jako chłonny i zasobny rynek, na którym mają szansę na sprzedaż importowanych chińskich towarów oraz dystrybucję różnorodnych dóbr konsumpcyjnych. Najmniej atrakcyjnymi czéściami Europy sa region skandynawski oraz państwa leżące $\mathrm{w}$ południowej części kontynentu. Udział chińskich firm w podziale na regiony w Europie przedstawia się następująco (Apoteker, Barthelemy i Lunven, 2013):

- Europa Środkowo-Wschodnia (55\%),

- Europa Zachodnia (29\%),

- Europa Południowa (12\%),

- Europa Północna (4\%).

Prywatne firmy działające w sektorze przemysłowym oraz przedsiębiorstwa państwowe inwestują głównie w Europie Zachodniej poprzez transakcje fuzji i przejęć europejskich firm, a także wejście na europejskie giełdy, skąd czerpia dodatkowy kapitał na rozwój. Dla dużych firm prywatnych i państwowych międzynarodowa ekspansja rynkowa jest naturalnym elementem rozwoju. Zazwyczaj są to podmioty o bardzo silnej pozycji na rynku chińskim, które poprzez dywersyfikację geograficzną swojej działalności poszukują nowych rozwiązań biznesowych mających na celu wzmocnienie ich pozycji na rynku krajowym. Ponadto, ze względu na atrakcyjność inwestycyjną oraz znacznie niższe koszty prowadzenia 


\begin{tabular}{|c|c|}
\hline Sektor & Nazwa i rodzaj inwestycji \\
\hline Sektor energetyczny & $\begin{array}{l}\text { - } \text { przejęcie przez Sinopec firmy Addax Petroleum (Szwajcaria) } \\
\text { - przejęcie przez Sinochem firmy Emerald Energy (Wielka Brytania) } \\
\text { - przejęcie przez China National Offshore Oil Corporation firmy Awilco Offshore (Norwegia) } \\
\text { - zakup przez China National Petroleum Corporation udziałów w INEOS (Francja) } \\
\text { - zakup przez State Administration of Foreign Exchange 1,6\% udziałów w Total (Francja) oraz } 1 \% \text { udziałów } \\
\text { w BP (Wielka Brytania) }\end{array}$ \\
\hline Sektor transportowy & $\begin{array}{l}\text { - przejęcie od Forda przez chiński koncern Zhejiang Geely Holding Group udziałów w Volvo Car } \\
\text { - przejęcie przez Great Wall Motors Litex Motors (Bułgaria) } \\
\text { - przejęcie przez China International Marine Containers firmy Burg Industries (Holandia) } \\
\text { - zakup przez Zhejiang Youngman Lotus I Pang Da Auto udziałów w Spyker Cars (Holandia) } \\
\text { - umowa COSCO Holdings na dzierżawę portu w Pireusie (w planach są inwestycje w porcie w Neapolu) }\end{array}$ \\
\hline Sektor nieruchomości & $\begin{array}{l}\text { - inwestycje w branży budowlanej Sany Heavy Industries (Niemcy) } \\
\text { - inwestycje w branży budowlanej Zoomlion (Włochy) } \\
\text { - inwestycje w branży turystycznej HNA (Hiszpania) } \\
\text { - inwestycje w branży turystycznej BCEGI (Grecja) }\end{array}$ \\
\hline Sektor finansowy & $\begin{array}{l}\text { - zakup przez CIC udziałów w Apax Finance (Wielka Brytania) } \\
\text { - zakup przez Ping An udziałów w Fortis (Belgia) } \\
\text { - zakup przez China Development Bank udziałów w Barclays (Wielka Brytania) } \\
\text { - zakup przez China International Trust and Investment Corporation udziałów w Cheuvrruex i CLSA (wcześniej } \\
\text { w Credit Agricole) (Francja) }\end{array}$ \\
\hline Sektor nowoczesnych technologii & $\begin{array}{l}\text { - zakup przez China Unicom udziałów w Telefonice (Hiszpania) } \\
\text { - przejęcie przez Lenovo firmy Medion (Niemcy) }\end{array}$ \\
\hline
\end{tabular}

Źródło: opracowanie własne na podstawie: Gradziuk i Szczudlik-Tatar (2012, s. 12), www.gochina.gov.pl (30.04.2014). 
działalności chińskie korporacje coraz cześciej lokują swoje inwestycje w regionie Europy Środkowo-Wschodniej (Apoteker, Barthelemy i Lunven, 2013). Zestawienie rozmieszczenia geograficznego chińskich przedsiębiorstw w Europie przedstawia rysunek 5 .

Rysunek 5. Rozmieszczenie geograficzne chińskich podmiotów gospodarczych w Europie w zależności od rodzaju firmy

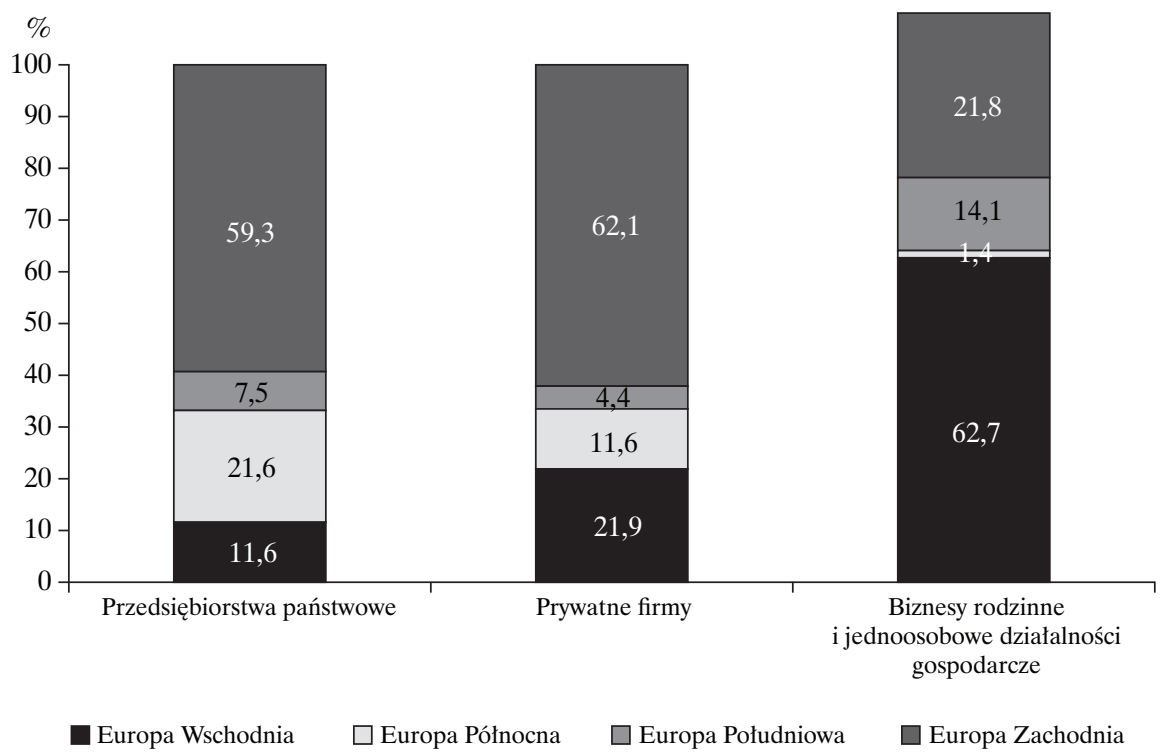

Źródło: opracowanie własne na podstawie: Antwerp Management School, Euro-China Investment Report 2013/2014, http://www.antwerpmanagementschool.be/en/faculty-research/research-projects/ euro-china-investment-report-2013-2014 (20.04.2014).

Inwestycje chińskich podmiotów w Europie Zachodniej oraz Środkowo-Wschodniej charakteryzują się odmiennymi cechami (tabela 2). Wskutek kryzysu ekonomicznofinansowego oraz pogorszenia otoczenia biznesowego w Europie Zachodniej chińscy inwestorzy zainteresowali się wschodzącymi gospodarkami Europy, w szczególności rynkiem polskim, gdzie napływa coraz więcej inwestycji kapitałochłonnych.

\section{Zakończenie}

Wskutek internacjonalizacji chińskiej gospodarki oraz aktywnego uczestnictwa w procesach globalizacji Państwo Środka uzyskało pozycje jednego $\mathrm{z}$ największych mocarstw gospodarczych na świecie. Dzięki zagranicznej polityce ekonomicznej ukierunkowanej na wejście w posiadanie unikalnych surowców naturalnych oraz dążeniu do pozyskania nowoczesnych technologii
Chiny umacniają swoją pozycję na arenie międzynarodowej. Ponadto, dzięki stymulowaniu innowacyjności w kraju, zachęcaniu przedsiębiorstw do ekspansji zagranicznej oraz ogromnym zasobom kapitałowym lokowanym w strategiczne projekty w różnych częściach świata Państwo Srodka jeszcze w I połowie XXI wieku ma szansę na uzyskanie statusu największego mocarstwa ekonomicznego i politycznego na świecie.

Przeprowadzone analizy wykazały, że w kwestii obrotów handlowych Chiny są jednym z najważniejszych partnerów dla Unii Europejskiej. Aktualnie, współpraca pomiędzy Chinami i Unią Europejską stanowi drugą największą platformę kooperacji gospodarczej na świecie. Dla Polski współpraca inwestycyjna stwarza możliwości dostępu do rynku chińskiego, który charakteryzuje się dużym potencjałem rozwoju. Dla strony chińskiej współpraca z Unią Europejską umożliwia chińskim 
Tabela 2. Porównanie charakterystyk chińskich przedsiębiorstw prowadzonych w krajach Europy Zachodniej oraz krajach Europy Środkowo-Wschodniej

\begin{tabular}{|c|c|c|}
\hline & Europa Zachodnia & $\begin{array}{c}\text { Europa } \\
\text { Środkowo-Wschodnia }\end{array}$ \\
\hline Typ firmy & $\begin{array}{l}\text { Głównie przedsiębiorstwa państwowe lub prywatne firmy } \\
\text { działające w przemyśle }\end{array}$ & $\begin{array}{l}\text { Jednoosobowe działalności gospodarcze lub } \\
\text { przedsiębiorstwa rodzinne }\end{array}$ \\
\hline Lokalizacja & $\begin{array}{l}\text { Skoncentrowane w regionalnych ośrodkach gospodarczych, } \\
\text { klastrach i strefach ekonomicznych }\end{array}$ & Aglomerowane w stolicach państw \\
\hline Główne sektory & Produkcja i dystrybucja dóbr przemysłowych hig-tech & $\begin{array}{l}\text { Pracochłonna produkcja niskiej techniki, sprzedaż } \\
\text { hurtowa i detaliczna dóbr konsumpcyjnych } \\
\text { (zwłaszcza tekstyliów) }\end{array}$ \\
\hline Rozmiar firmy & Duże i średnie przedsiębiorstwa & Mikro i małe przedsiębiorstwa \\
\hline Forma wejścia & Inwestycje typu greenfield oraz przejęcia istniejących firm & Inwestycje typu greenfield \\
\hline Ewolucja firm & $\begin{array}{l}\text { - Wieloletnie przedsiębiorstwa państwowe sektora } \\
\text { handlowego i żeglugowego, } \\
\text { - Projekty inwestycje dużych grup kapitałowych (głównie } \\
\text { sektor przemysłowy), } \\
\text { - Przejmowane biznesy rodzin europejskich przez państwowe } \\
\text { i prywatne firmy chińskie. }\end{array}$ & $\begin{array}{l}\text { - Firmy założone głównie około roku } 2000 \\
\text { przez przedsiębiorców - imigrantów z zagranicy, } \\
\text { - Rosnąca liczba przemysłowych grup kapitałowych } \\
\text { rozpoczynających produkcję dóbr konsumpcyjnych. }\end{array}$ \\
\hline Kooperacja & Głównie z lokalnymi firmami & $\begin{array}{l}\text { Głównie z chińskimi firmami krajowymi i } \\
\text { zagranicznymi }\end{array}$ \\
\hline
\end{tabular}

Źródło: opracowanie własne na podstawie: Apoteker i in. (2013, s. 15-17). 
podmiotom gospodarczym wejście na największy rynek na świecie, a także dostęp do nowych technologii oraz wykształconej i wykwalikowanej siły roboczej. Dzięki poszerzeniu Unii Europejskiej o nowych członków z Europy Środkowo-Wschodniej znacznemu obniżeniu uległy koszty pracy. Ponadto, do wspólnego obszaru celnego włączono dynamiczne europejskie gospodarki charakteryzujące się rosnącym popytem wewnętrznym. Z perspektywy Wspólnoty Europejskiej dla poprawy wzajemnych relacji gospodarczych istotne są zmniejszenie nierównowagi w zakresie wymiany handlowej oraz stymulacja europejskiego eksportu do Azji. Unijna oferta eksportowa ma szansę odnieść sukces w Chinach w branży dóbr luksusowych oraz motoryzacji. Istotnym przedsięwzięciem na przyszłość jest poprawa warunków dla inwestorów zagranicznych w Chinach, dzięki którym europejskie przedsiębiorstwa będą miały możliwość rozwijania działalności.

\section{Bibliografia}

Antwerp Management School (2013). Euro-China Investment Report 2013/2014. Pozyskano z: www. ccilc.pt (20.04.2014).

Apoteker T., Barthelemy S. I Lunven S. (2013) EU - China FDI in the 21st century: Who is ready for a 'win - win' strategy?, Conference on EU and the Emerging Powers, European Parliament. Pozyskano z: www.usaintlouis.be (11.04.2014).

European Commision (2014). Facts and figures on EU - China trade, March 2014. Pozyskano z: http:// ec.europa.eu (07.04.2014).
European Commision Directorate General for Trade, China - Trade Statistics 2013. Pozyskano z: http://ec.europa.eu (07.04.2014).

EU-China 2020 Strategic Agenda for Cooperation. Pozyskano z: http://eeas.europa.eu/ (15.04.2014).

European Union Framework Contract Commission 2011 (2013). EU-China Economic Observatory. Pozyskano z: http://trade.ec.europa.eu (08.04.2014).

Góralczyk, B. (2013). Przebudzenie smoka. Powrót China na scene globalna. Warszawa: Wydawnictwo Rambler.

Gradziuk, A. i Szczudlik-Tatar, J. (2012). Perspektywy rozwoju współpracy gospodarczej Polski z Chińską Republiką Ludową, Raport Polskiego Instytutu Spraw Międzynarodowych. Pozyskano z: www.gochina.gov.pl (30.04.2014)

Gradzka, D. i Kania, A. (2010). Wspótpraca Chin i UE: Specyfika wzajemnych stosunków handlowych. Centrum Studiów Polska-Azja. Pozyskano z: www. polska-azja.pl (09.04.2014).

Pieczonka, A. (2012). Chińskie „Go Global”. Dylematy $i$ wyzwania dla Chińskiego Smoka, Szanghaj. Pozyskano z: www.gochina.gov.pl (02.02.2014).

Puślecki, Z.W. (2012). Relacje Unii Europejskiej z Chińską Republiką Ludową wobec wyzwań gospodarki globalnej 2012. Wyzwania gospodarki globalnej. Prace i Materiaty Instytutu Handlu Zagranicznego Uniwersytetu Gdańskiego, 31/1, Gdańsk: Wydawnictwo Uniwersytetu Gdańskiego.

Zhang J. (2011). The EU - China relationship arriving at a bottleneck - A look at the ongoing negotiation of the PCA. College d'Europe, Department of EU international relations and diplomacy Studies. Pozyskano z: www.coleurope.eu (01.10.2014). 